\title{
Optimizing nitrogen rates in the midwestern United States for maximum ecosystem value
}

\author{
$\underline{\text { Patrick M. Ewing }}^{1}$ and Bryan C. Runck ${ }^{2}$
}

\begin{abstract}
The importance of corn production to the midwestern United States cannot be overestimated. However, high production requires high nitrogen fertilization, which carries costs to environmental services such as water quality. Therefore, a trade-off exists between the production of corn yield and water quality. We used the Groundwater Vulnerability Assessment for Shallow depths and Crop Environment Resource Synthesis-Maize models to investigate the nature of this trade-off while testing the Simple Analytic Framework trade-offs featured in this Special Feature. First, we estimated the current levels of yield and water quality production in northeastern Iowa and southern Minnesota at the 1-square-kilometer, county, and regional scales. We then constructed an efficiency frontier from optimized nitrogen application patterns to maximize the production of both yield and water quality. Results highlight the context dependency of this trade-off, but show room for increasing the production of both services to the benefit of all stakeholders. We discuss these results in the context of spatial scale, biophysical limitations to the production of services, and stakeholder outcomes given disparate power balances and biophysical contexts.
\end{abstract}

Key Words: agriculture; agroecology; corn belt; DSSAT; fertilization rate; frontier analysis; groundwater nitrate; GWAVA-S; land use; nitrogen; rotation; row crops; Simple Analytics Framework; yield

\section{INTRODUCTION}

In 1975, corn covered 77.5 million acres in the United States (Crop Reporting Board 1975), and by 2012, corn's planted area had grown to a record high of roughly 97 million acres (National Agricultural Statistics Service 2012a). The proliferation of corn has impacted midwestern U.S. agroecosystems environmentally, economically, and socially, particularly through the use of nitrogen $(\mathrm{N})$ fertilizer. Nitrogen is the most limiting of the three macronutrients in U.S. corn production (Osborne 2002) and was applied to $97 \%$ of all corn cropland in 2010 (National Agricultural Statistics Service 2011).

The services and disservices of agricultural $\mathrm{N}$ use cross multiple scales and socioeconomic contexts, and influence a diverse array of stakeholder groups (Ribaudo et al. 1999, 2011). Rural livelihoods depend on high-yielding corn production and, therefore, on inputs of synthetic $\mathrm{N}$ fertilizer; additionally, highyielding corn production is an ecosystem service that meets national demands for feed and fuel (Baker and Zahniser 2006, Marsh 2007, Bierman et al. 2011). However, N pollution harms stakeholders as diverse as the fishing industry in the Gulf of Mexico (Diaz and Rosenberg 2008) and Iowa citizens who drink local water (Powlson et al. 2008). These disservices result not only in the destruction of ecosystems, but also economic loss for local communities and individuals. Because agricultural $\mathrm{N}$ pollution has no single source, society can hold no single entity liable. As a result, $\mathrm{N}$ management is debated across many spatial scales, from subfield to global (Tyrrell 1999, Nolan and Hitt 2006, Polasky et al. 2011, Keeler et al. 2012, Mueller et al. 2012). At the center of this debate is the fact that synthetic $\mathrm{N}$ use often results in in both higher yield and increased nitrate pollution. Essentially, a tradeoff exists between the production of water quality, which is decreased by nitrate pollution, and the production of corn yield.

Because $\mathrm{N}$ produces both services and disservices, it has created tension and confusion around what constitutes appropriate $\mathrm{N}$ management. Local presses have covered this debate for the past decade (Meersman 1999, Marcotty 2012). Even among agricultural universities, different researchers have promoted divergent fertility management methods ranging from minimal use of synthetic fertility (Gallandta et al. 1999, Good and Beatty 2011) to heavy utilization of all inputs (Bender et al. 2013). These divergent perspectives result in a variety of $\mathrm{N}$ management practices recommended for corn farmers to maximize ecosystem services and minimize disservices. Recommendations range from increasing $\mathrm{N}$ use efficiency through technology (McBratney et al. 2005 ) to diversifying crop rotation and decreasing synthetic $\mathrm{N}$ inputs (Porter et al. 2006, Davis et al. 2012). In reality, appropriate $\mathrm{N}$ use can be heavily context dependent, which makes understanding landscape variability an essential component of optimum $\mathrm{N}$ use for maximum ecosystem services (Sawyer et al. 2006, Rajsic and Weersink 2008). As a result, divergent stakeholder values cannot be equally met across diverse biophysical contexts.

Different stakeholder groups value water quality and yield differently, and their decision making around $\mathrm{N}$ use reflects these preferences. In the focus region of this paper, north-central Iowa and southern Minnesota, farmers produce some of the highest rainfed corn yields in the world (National Agricultural Statistics Service 2012b). At the same time, residents of this region may pay more than US\$4.00 per 1000 gallons of water so that local water supplies meet U.S. Environmental Protection Agency standards of 10 milligrams of nitrate per liter (Powlson 2008, Pitt 2013). This cost stands in contrast to US $\$ 0.05$ per 1000 gallons when nitrate removal is not needed (Pitt 2013). Further examples are highlighted in a 2013 popular press article, in which a farmer stated "we like to farm, but we also like to make money at it" in trying to illustrate the essential role $\mathrm{N}$ fertilizer plays in profitable corn production (Pitt 2013). In the same article, a researcher discussed the ecological and human health issues without mentioning farmer economic impacts (Pitt 2013). Even the abovementioned academic literature on $\mathrm{N}$ management assumes the value of high yield, whereas the assumed value of yield may be

${ }^{1}$ University of Minnesota, Department of Agronomy and Plant Genetics, ${ }^{2}$ University of Minnesota, Department of Geography, Environment and Society 
less pronounced in other literatures whose primary concern is not crop production (Turner and Rabalais 2003, Viscusi et al. 2008). Still, in light of these conflicting demands and perspectives, can this region achieve high corn yields without harming human health or the environment? This question is far from resolved from a societal perspective.

Although the trade-off between water quality and yield is well documented at the watershed, basin, and global scales (Donner and Scavia 2007, Polasky et al. 2008, Johnson et al. 2012, Mueller et al. 2012), specific $\mathrm{N}$ dynamics at the field scale, i.e., the scale of decision making, remain ambiguous (Sawyer et al. 2006). To satisfy all stakeholders, an optimum scenario would reduce $\mathrm{N}$ pollution in ways that acknowledge not only field scale or watershed dynamics, but also maintain or increase corn yield. However, at this point in time, whether this win-win scenario exists at regional or finer spatial scales is unclear.

To explore the biophysical feasibility of achieving such an optimum scenario, we used the Simple Analytic Framework (SAF) of Cavender-Bares et al. (2015). The SAF explores the efficiency of resource utilization in social-ecological systems to provide socially and ecologically important ecosystem services. Building on previous work in welfare economics (Bator 1957) and inclusive wealth (Arrow et al. 2004), the SAF seeks to (1) constrain the biophysical system through an efficiency frontier, which delimits the simultaneous production of multiple ecosystem services; (2) integrate stakeholder values with the efficiency frontier through indifference curves; (3) identify obstacles to achieving desired outcomes; and (4) explore zones of resilience, temporal dynamics, and time lags (Cavender-Bares et al. 2015). The SAF intends to engage stakeholders through the consideration of both what is biophysically possible and what is socially optimal. In focusing on $\mathrm{N}$ pollution associated with northern Iowa and southern Minnesota corn production, we only fully utilized the first and third of those four components, but acknowledge that stakeholder engagement and zones of resilience, temporal dynamics, and time lags should be primary goals in future work.

We applied the SAF to the trade-off between water quality and corn yield in southern Minnesota and northern Iowa. We used a combination of the GroundWAter Vulnerability Assessment for Shallow depths (GWAVA-S) model (Nolan and Hitt 2006) and the Crop Environment Resource Synthesis (CERES) Maize (CERES-Maize) model housed in the Decision Support System for Agrotechnology Transfer (DSSAT; Jones et al. 2003). Our goals were to use the SAF and models to (1) discern the biophysical limits of corn and water quality production in this region by creating an efficiency frontier; (2) compare current $\mathrm{N}$ use outcomes to the efficiency frontier; and (3) frame the discussion of context-dependent, optimal $\mathrm{N}$ rates, given stakeholder values.

\section{METHODS}

\section{Study area and model selection}

The study region (Fig. 1) covers 31 counties in southern Minnesota and northern Iowa and lies at the heart of the U.S. corn belt. This region features the highest rainfed corn yields in the country as well as some of the highest nitrate pollution levels
(National Agriculture Statistics Service 2007, Pitt 2013). The region also features a variety of soil textures and an extensive network of groundwater monitoring sites, and key data are available for both crop and water quality models. Cropland in this region is largely devoted to corn or soybeans (Fig. A1.1). Our chosen models, GWAVA-S and CERES-Maize, simulate groundwater nitrate pollution and corn yields based on $\mathrm{N}$ fertilizer application rates, land use, and soil properties (Jones et al. 2003, Nolan and Hitt 2006). We did not expect our results to reflect absolute groundwater nitrate levels or crop yields. We did, however, expect both models to capture relative changes in both yield and nitrate pollution across soil types and fertilizer application rates.

Fig. 1. Map of study site, located the north central region of the United States. Data were aggregated at the county and study area levels. County data explicitly discussed are from Watonwan (6), Freeborn (10), Butler (32), and Pocahontas (27) counties (Giglierano and Mohan 1990, Minnesota Department of Natural Resources 2003, National Atlas of the United States 2012).

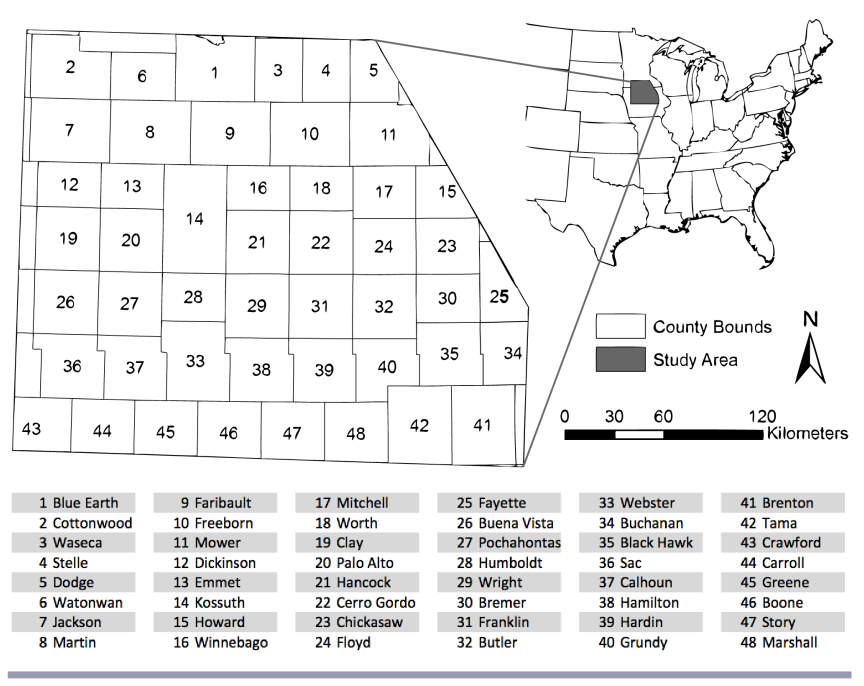

We used ArcGIS 10.0 (Environmental Systems Research Institute 2010) to perform spatial operations and R 2.14.1 for all other calculations and plotting using the packages base ( $\mathrm{R}$ Development Core Team 2011), data.table (Dowle et al. 2013), ggplot2 (Wickham 2009), plyr (Wickham 2011), and sqldf (Grothendieck 2012).

\section{Water quality}

We estimated groundwater nitrate pollution resulting from synthetic fertilizer application to corn using GWAVA-S (Nolan and Hitt 2006). GWAVA-S is a nonlinear model that produces output at a $1-\mathrm{km}^{2}$ resolution, which provides adequate resolution to create an efficiency frontier. Its parameters are intuitive, well defined, and readily accessible as spatial data from public databases. Although it is a national-scale model, previous validation of GWAVA-S showed an error of less than $1.6 \mathrm{ppm}$ of nitrate at multiple points in the study region (Nolan and Hitt, 2006), indicating it captures relative nitrate dynamics accurately across this region. 
GWAVA-S is divided into three sections: $\mathrm{N}$ input $\left(N_{\mathrm{j}}\right)$, Transportation ( $T$.). and Attenuation $(A$ ):

$$
c_{g w i}=\left(\sum_{n=1}^{N} \beta_{n} X_{n i}\right) \cdot T_{i} \cdot A_{i} \cdot \varepsilon_{i}
$$

Both $T_{\mathrm{i}}$ and $A_{\mathrm{i}}$ are exponential functions calculated for each grid cell $i$ from input parameters that, in our study region, exclusively consisted of soil properties. $T_{\mathrm{i}}$ and $A_{\mathrm{i}}$ were calculated in ArcGIS 10.0 (Environmental Systems Research Institute 2010) based on precompiled layers (Nolan and Hitt 2006). $N$ input is a linear function of land use variables $\left(X_{n}\right)$ adjusted by a constant $\left(\beta_{n}\right)$; we used only synthetic farm fertilizer (FFERT) to calculate $N$ input. FFERT for all scenarios was calculated assuming that only cropland in corn received fertilization. Initial fertilizer application rates ranged from 0 to $250 \mathrm{~kg} \mathrm{ha}^{-1}$ in $10-\mathrm{kg} \mathrm{ha}^{-1}$ increments. We then rescored GWAVA-S outputs on a 0-1 relative scale, where 1 equaled the 99.7th percentile of all GWAVA-S outputs. We then subtracted this number from 1 to score water quality.

\section{Corn yield}

We estimated corn yield as a function of $N$ input rates and soil texture using the CERES-Maize model (Jones et al. 2003). The CERES-Maize model is a time-step model that simulates corn crop growth, development, and yield as a function of soil-plantatmosphere dynamics, but does not include tillage. The model is capable of determining crop yield variability in response to soil, weather, and management choices across regional landscapes (Jagtap and Jones 2002). The minimum input data set for the study region is available through DSSAT (Jones et al. 2003).

The model input data set featured soil texture, initial soil conditions for moisture and fertility, weather, corn variety, planting date, and fertilizer application rate and type. We used existing parameters within the DSSAT framework from previous studies conducted in Iowa for soils, weather, and corn variety. Soil texture classifications included sandy loam, sandy clay, and silty loam at three depth classes. We used 1990 weather data from the Iowa State University Agronomy Farm in Ames, Iowa; 1990 was a representative weather year in this region in terms of rainfall distribution and daily temperatures. Moreover, the hypoxic zone in the Gulf of Mexico was moderately sized in this year; one cause of the hypoxic zone is farm nitrate runoff, which varies with weather patterns (Donner and Scavia, 2007). Management parameters and crop varieties were based on best management practices within the constraints of CERES-Maize options (Table A1.1). We used CERES-Maize outputs to generate yield response curves to $\mathrm{N}$ application rates (anhydrous ammonia) of $0 \mathrm{~kg} \mathrm{ha}^{-1}$ and $75-350 \mathrm{~kg} \mathrm{ha}^{-1}$ at $25-\mathrm{kg}$ intervals for each combination of soil texture, variety, and $\mathrm{N}$ application rate.

CERES-Maize yield outputs were exported to $\mathrm{R}$ ( $\mathrm{R}$ Developmental Core Team 2011), and quadratic-linear regressions of yield as a function of $\mathrm{N}$ application rate were estimated for each soil texture (Table A1.1). From these regressions, we calculated average yield in each $1-\mathrm{km}^{2}$ grid cell that corresponded to a GWAVA-S output. Surface texture was categorized from STATSGO data to match input textures of CERES-Maize (Table A1.1) and generalized in ArcGIS 10.0 to $1-\mathrm{km}^{2}$ grid cells corresponding to GWAVA-S output (Environmental Systems Research Institute 2010). The yield potential $Y_{\mathrm{ij}}$ of each grid cell $i$ at a fertilization rate $j\left(\mathrm{~kg} \mathrm{ha}^{-1}\right)$ was calculated as the average of each soil type's regression curve weighted bv the percent representation of each soil tvpe:

$$
Y_{i j k}=\sum_{k=1}^{K} y_{i j k} a_{k}
$$

$y_{\mathrm{ijk}}$ is the yield for soil type $k$ in grid $i$ at fertilization rate $j$, and $a_{\mathrm{k}}$ is the percent area of soil type $k$ in the grid cell. As with the GWAVA-S model, fertilizer rates ranged from 0 - to $250-\mathrm{kg} \mathrm{N} \mathrm{ha}^{-1}$ in $10-\mathrm{kg} \mathrm{N} \mathrm{ha}^{-1}$ increments. From yield potential, we calculated total yield given the acres of corn planted in each cell according to the 2012 crop data layer (Appendix 1). Both total yield and yield potential were rescored on a $0-1$ scale relative to the maximum of the study area. We validated yield responses to $\mathrm{N}$ application rates by comparing CERES-Maize output with reported county-wide data (National Agricultural Statistics Service 2012c).

\section{Creating efficiency frontiers}

We used GWAVA-S and CERES-Maize outputs to define efficiency frontiers at the county- and study-area scales. Efficiency frontiers describe the maximum amount of water quality that can be produced given yield, and vice versa. The trade-off between water quality and yield was visualized for the study area (Fig. 2) and individual counties (Fig. 3). We did this for three scenarios: a nonoptimized scenario, assuming equal $\mathrm{N}$ application across all corn cropland; a current-state scenario that used reported average county-wide N application rates (Ruddy et al. 2006); and an optimized scenario to maximize the production of water quality and yield at a given average $\mathrm{N}$ application rate. Countywide points for water quality and yield potential were averaged across each county (Appendix 1).

To estimate the limit of production potential assuming even $\mathrm{N}$ application in a nonoptimized scenario, we averaged water quality and yield for each $\mathrm{N}$ application rate. Data was averaged both by county and by study area. We estimated the current system state for Iowa and Minnesota based on total fertilizer purchased in each county in 2001 (Ruddy et al. 2006), assuming purchased N was applied evenly across corn cropland. We calculated per hectare application rates based on the area of land in corn production in 2001 derived from the National Agricultural Statistics Service Quickstats database (National Agricultural Statistics Service 2012c). Then, we used this N rate to calculate water quality and yield using the above-mentioned models.

To calculate an optimized efficiency frontier, we first created a set of linear utility preferences representing potential trade-offs a stakeholder would be willing to make between yield and water quality. Slopes of utility preferences ranged from -0.05 to -50 on an exponential scale. For example, if a stakeholder's trade-off preference were -0.625 , a decrease in water quality of $0.5(0-1$ relative scale) would be acceptable if yield increased by 0.8 (0-1 scale); a trade-off preference of zero would indicate that a stakeholder only values water quality. We then estimated the slope of the curve that represents the trade-off between relative yield and water quality for each $1-\mathrm{km}^{2}$ grid cell in the nonoptimized scenario. This slope equaled the change in water quality divided by the change in corn yield as $\mathrm{N}$ application rates increased. Then, we selected the ideal $\mathrm{N}$ application rates for each utility preference as the higher of the pair of $\mathrm{N}$ rates whose trade-off slope closest matched each utility preference. As with the nonoptimized 
Fig. 2. Current production of ecosystem services in our study area. Optimized and nonoptimized data are model outputs for each grid cell in the study area; stronger colors indicate a greater concentration of outputs at a given water quality and yield and indicate the range of variation that each dataset presents. Nonoptimized data was subsampled randomly to ensure an equal number of data points between the datasets. Frontiers are the mean of all data in the corresponding sets. Current county averages are estimated based on reported, uniform $\mathrm{N}$ application rates for each county in 2001 (Ruddy et al. 2006). Scales are relative to a set maximum (see text).

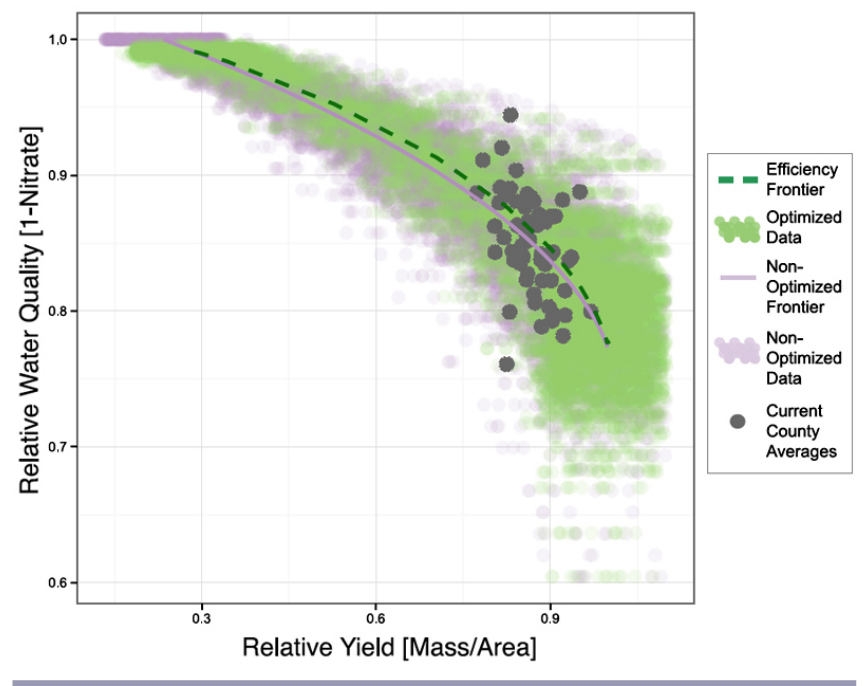

Fig. 3. Efficiency frontiers and nonoptimized frontiers of Butler and Pocahontas Counties illustrate counties within the study area that fall on the calculated efficiency frontier. Freeborn County illustrates a moderate potential for improvement through optimizing $\mathrm{N}$ rates, and Watonwan County illustrates a county with high potential for improvement through optimizing $\mathrm{N}$ rates.

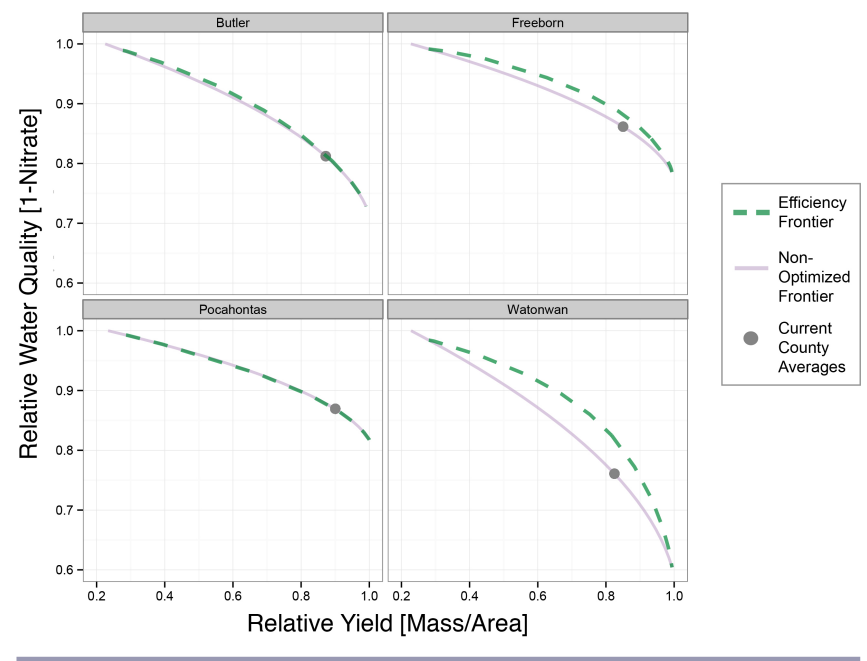

scenario, we then calculated the efficiency frontier for each county and the study area by averaging relative yield and water quality at each $1-\mathrm{km}^{2}$ grid for each utility preference.

\section{Effectiveness of optimization}

At both the study area and county levels, we calculated the effectiveness of optimizing $\mathrm{N}$ application rates relative to even application rates at the median total yield. This yield corresponded to a utility preference of $\mathrm{u}=-1.0$, where water quality and yield are equally valuable. We then interpolated the amount of water quality that would be produced at this same yield potential under the nonoptimized $\mathrm{N}$ application scenario based on the average county $\mathrm{N}$ application rate at this utility preference. The percent difference between the optimized and nonoptimized water qualities represented the relative improvement in water quality when moving from the nonoptimized, even application rate scenario to the optimized scenario at this median yield.

To explore how environmental heterogeneity interacts with impact of optimization, we regressed the percent improvement in water quality against increasingly complex measures of variability in the physical environment of each county. These measures were percent soil type $k$, where $k$ is one of the four general soil types used in the CERES-Maize model; Simpson's diversity $(S)$ of general soil type, calculated from percent representation of each soil type $x$ in the county; and the combined standard deviation of the transportation and attenuation factors of GWAVA-S, which aggregates soil type and other biophysical parameters (Nolan and Hitt 2006). The GWAVA-S-based aggregation is an alternative to aggregation by land capability class: land capabilities are a function of the GWAVA-S parameters, soil texture, and slope, as well as other factors including waterlogging frequency and pan formation that do not readily fit into either GWAVA-S and CERES-Maize (Soil Conservation Service 1961). All data were transformed as necessary to meet normality assumptions prior to regression.

\section{Validation}

Briefly, we converted reported yields to values relative to the maximum outputs we modeled. We then regressed the reported yield potentials against calculated yield potentials for corn based on $\mathrm{N}$ application rates described by Ruddy et al. (2006). Finally, the difference between the reported relative yield potential and the estimated relative yield potential based on reported $\mathrm{N}$ rates was calculated as the model's error. We tested these data for homogeneity of variance in the error term using Bartlett's test $(\mathrm{R}$ Development Core Team 2011).

\section{RESULTS}

The reported county averages for yield all fell above $70 \%$ of the maximum modeled at any single $1-\mathrm{km}^{2}$ grid, which illustrates the preference for corn production in the study area. Furthermore, reported county averages for $\mathrm{N}$ fertilization confirmed that variability exists among counties in the water quality-yield tradeoff (Fig. 2). The studywide efficiency frontier, calculated from the optimized scenario, illustrates a clear trade-off between water quality and yield that increases in severity as the maximum of either service is approached; at relatively high yields, a small further gain in yield requires a significant loss in water quality. The range of water quality and yield response to $\mathrm{N}$ varied across the study area, but the optimized data appeared to decrease in 
variability. Through spatially optimizing $\mathrm{N}$ application rates for each county, the optimized study area could potentially produce more ecosystem services per square kilometer.

Different counties show contrasting trade-offs between ecosystem services (Fig. 3). For some counties in our study area, such as Freeborn, Pocahontas, and Butler, the nonoptimized production curve was close or even equivalent to the efficiency frontier, which indicates that these counties are maximizing or nearly maximizing ecosystem service production of these two variables. Other counties, such as Watonwan, are operating well below the efficiency frontier. To explain this difference, we regressed percent improvement against measures of variability within counties. Percent soil type and soil type diversity did not show a significant relationship with water quality improvement within the assumptions of linear regressions (data not shown), but the variation in GWAVA-S transportation and attenuation parameters was both positive and highly significant $(\mathrm{P}<0.001$; Fig. 4).

Comparing Pocahontas and Watonwan counties further highlights the importance of biophysical environment in defining the optimal $\mathrm{N}$ application rates to maximize ecosystem service production. For example, in Pocahontas County, the optimal N

Fig. 4. Relationship between variability in GWAVA-S transportation and attenuation parameters, and the improvement in water quality between optimized and nonoptimized nitrogen application rates. Points are aggregated at the county scale. The GWAVA-S parameters were cube-root transformed prior to calculating the standard deviation. The linear model $(\mathrm{R} 2=0.3516)$ shows an intercept of $-0.0085+/$ $0.0026(\mathrm{P}<0.002)$ and a slope of $0.243+/-0.049(\mathrm{P}<<0.001)$. The shaded area represents the standard error of the regression. One outlier (Watonwan County) was removed prior to regression because of over-leveraging; this did not affect the significance of the positive relationship.

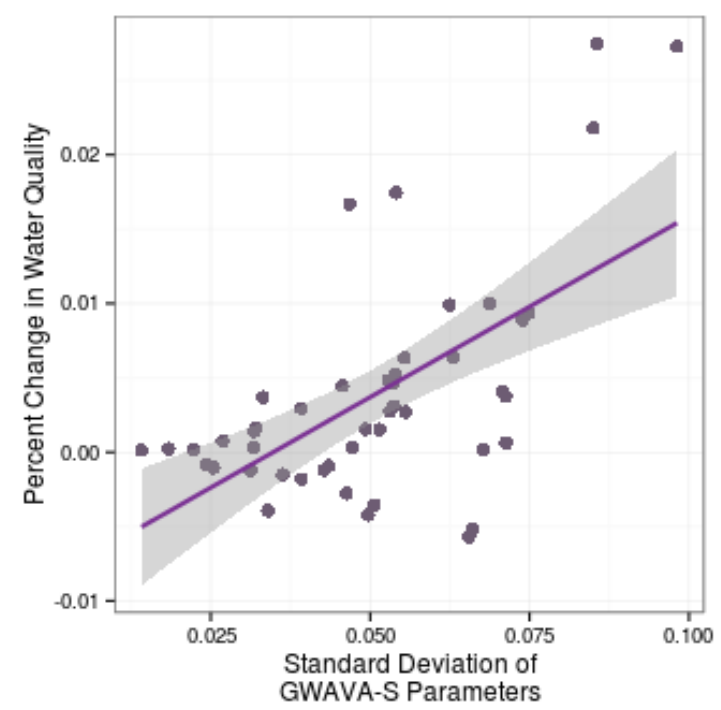

application rates at each grid cell and utility were less variable than in Watonwan County (Fig. 5), which indicates a more homogenous biophysical environment (Fig. A1.2). This homogenous biophysical environment allows for a more homogenous production of water quality and yield across $\mathrm{N}$ rates. In contrast, as median $\mathrm{N}$ rate increased, Watonwan's yield and water quality variability among grid cells also greatly increased. In parallel, at a given utility preference, Watonwan County produced less yield on average compared with Pocahontas County because of a large proportion of cropland that would receive little to no $\mathrm{N}$ application. Despite this yield loss, median water quality in Watonwan was also slightly less than in Pocahontas. Therefore, counties such as Watonwan County seemingly have the opportunity for great gains without having to sacrifice either water quality or yield, whereas Pocahontas County appears to already be at the edge of efficiency without optimization (Figs. 4 and 5).

Fig. 5. Plots illustrate the range of potential responses across utilities based on context. Pocahontas County illustrates a county with a tight response across utility preferences, whereas Watonwan County increases in variability as utility preference for yield increases.
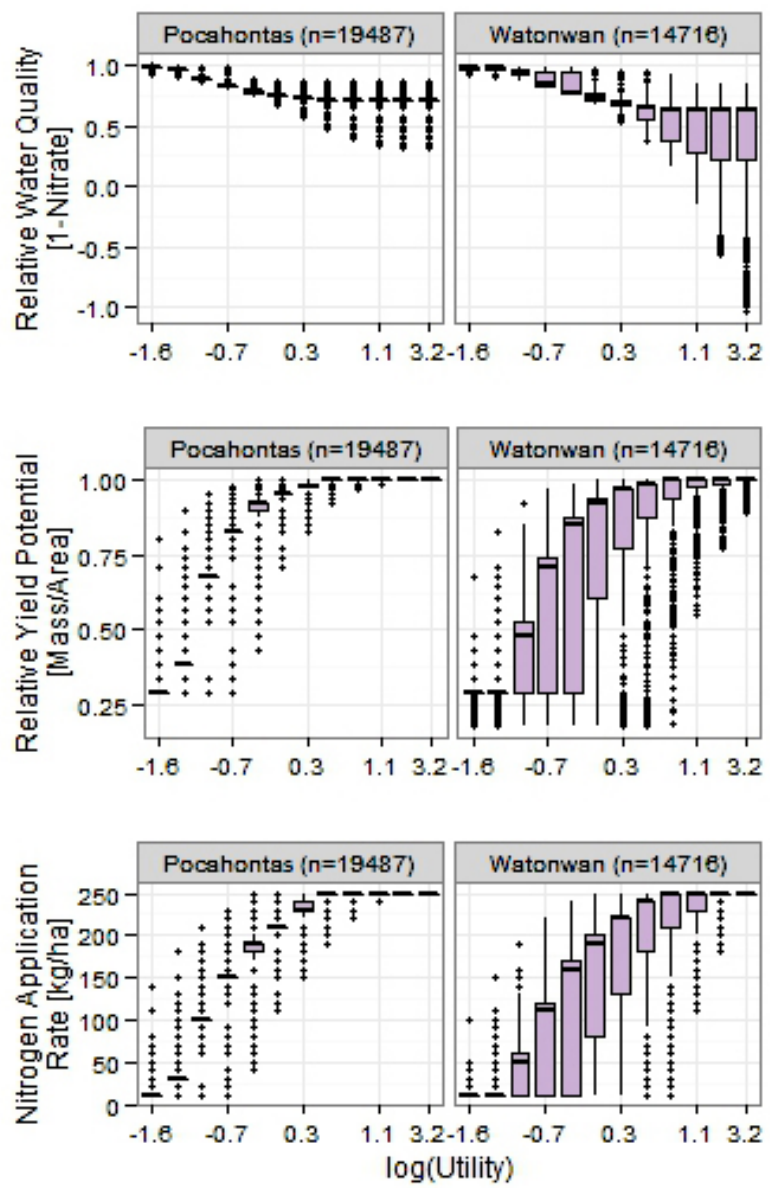
Depending on the mixture of environment and preference, the optimal amount of $\mathrm{N}$ applied changes at varying rates with utility across the landscape. Figure 6 a shows optimal $\mathrm{N}$ application rates under a scenario where water quality is highly valued; therefore, applying little to no $\mathrm{N}$ to most areas maximizes utility. Figure $6 \mathrm{c}$ shows the exact opposite, with a high preference for yield generally resulting in high application rates. The average reported $\mathrm{N}$ application rate across the four focus counties, Watonwan, Pocahontas, Butler, and Freeborn, is $156 \mathrm{~kg} \mathrm{~N} \mathrm{ha}^{-1}$, which falls within the $\mathrm{N}$ ranges of Figures $6 \mathrm{~b}$ and $6 \mathrm{c}$.

Fig. 6. Maps show $\mathrm{N}$ application rate for three utility preferences; a) Illustrates a utility preference of -0.3 preferring water quality resulting in a low $\mathrm{N}$ application rate across the study area; b) Shows a utility preference of -0.7 , a moderate utility preference. $\mathrm{N}$ application rates reflect the moderation resulting in a large range of application rate based on spatial context; c) Illustrates a utility preference of -2.3 preferring yield resulting in high $\mathrm{N}$ application rates across the study area.
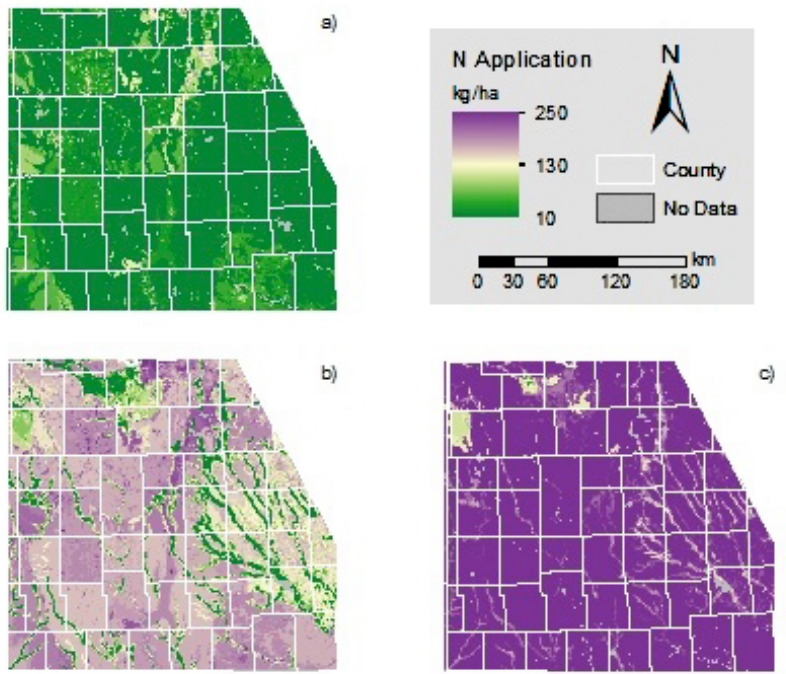

\section{DISCUSSION}

We began this analysis with two questions. (1) Can the study area produce more yield and more water quality given regional biophysical constraints? (2) If so, where and how can these increases occur? Our results demonstrate that yes, it is possible to increase corn yield and water quality within the study region. Figure 2 illustrates a clear difference between nonoptimized $\mathrm{N}$ use and optimized $\mathrm{N}$ use. This difference represents the potential for large gains within the study area across most stakeholder values. However, study area-wide gains would require disproportionate changes in $\mathrm{N}$ use across the landscape regardless of utility (Fig. 6).

Demonstrating this scale dependence are the contrasting environmental contexts of Watonwan and Pocahontas counties. Watonwan County has a highly heterogeneous soil environment (see Fig. 5 and Fig. A1.2); Pocahontas County is comparatively homogenous. When $\mathrm{N}$ applications were optimized, Watonwan County also showed the largest gain in water quality while maintaining yield; Pocahontas County's gain was minimal. Pocahontas County could maintain relatively high water quality even under a high utility preference for yield and high $\mathrm{N}$ application rates. In contrast, in Watonwan County, the water quality impacts of a high corn preference were greater; therefore, optimal management choices in this county would feature lower $\mathrm{N}$ applications. Any concerted effort to optimize $\mathrm{N}$ use across this study region, be it through public policy or some other means, should focus on Watonwan County and similarly heterogeneous environments first.

Generalizing this inference, optimization effectiveness is strongly and positively correlated with environmental heterogeneity (Fig. 4). A major driving environmental factor behind this trend is soil texture. Both the transportation of $\mathrm{N}$ to groundwater in the GWAVA-S model and crop responses to $\mathrm{N}$ in the CERES-Maize model (Jagtap and Jones 2002, Nolan and Hitt 2006) are highly dependent on soil texture. As a result, soil texture dramatically impacts the nature of the trade-off between water quality and yield. However, many other factors are important in the water quality response to optimization at the county scale, including topography and surface drainage (Nolan and Hitt 2006). Therefore, a quick, broad measure of environmental heterogeneity as in Fig. 4 could be an effective way to select intervention areas that maximize the impact of an optimization program.

This context dependence also has important implications at the farm scale, especially in navigating land manager preferences for different ecosystem services. A land manager holding a balanced preference between water quality and yield likely would apply more $\mathrm{N}$ in Pocahontas County than in Watonwan County. The analysis illustrates how biophysical contexts constrain individuals' or groups' realizations of values through the nature of the trade-off. From an individual farmer's perspective, optimization on such a large spatial extent could cause inequity. At the county scale, a primary unit of landscape policy implementation, optimization could potentially require some farmers to decrease $\mathrm{N}$ inputs below a profitable application rate. In the context of existing perceptions surrounding private property rights in the United States, requiring farmers to decrease $\mathrm{N}$ inputs, and thereby potentially decrease yield or profitability, might require payment for the resulting increases in water quality from which the individual farmer may or may not directly benefit.

Such disparate biophysical contexts also highlight the importance of power balances among stakeholders. Even if powerful stakeholders in Pocahontas County prefer water quality, the county can produce much corn and satisfy those who would prefer that good, and produce a high aggregated utility. Yet in Watonwan County, stakeholders valuing water quality would receive less value from land management by a powerful minority who might place a higher value on corn yield. The result in Watonwan County is a reduction of the overall benefit of ecosystem services received in this county. Given the current context of U.S. agriculture, with fewer than $1 \%$ of the population claiming farming as an occupation (National Agricultural Statistics Service 2009), few people have a voice in $\mathrm{N}$ management because decisions are primarily made at the field scale by landowners and their crop advisors. Unfortunately, in many contexts, some parties, i.e., fishermen or public water drinkers of Des Moines, Iowa, could 
share a disproportionate amount of the burden associated with the disservices of $\mathrm{N}$ application. At the same time, one could imagine a "polluter pays" policy scenario involving a synthetic $\mathrm{N}$ application limit, in which all farmers regardless of biophysical context would be required to apply similarly less synthetic $\mathrm{N}$ fertilizer. Although this policy would decrease nitrate pollution, it could also needlessly decrease corn yield, resulting in suboptimal system performance. This point should raise concerns surrounding the equitable distribution of N-related ecosystem services and disservices.

On the other hand, the existence of inefficiencies suggests a market-based opportunity to optimize $\mathrm{N}$ use efficiency and the production of ecosystem services. Growers certainly have an incentive to maximize $\mathrm{N}$ efficiency with $\mathrm{N}$ inputs estimated at more than US\$100 per acre in 2013 within the study region (Duffy 2013). A business or community initiative that can organize a paysharing or similar agreement between land managers and water users to help mitigate farmer transition risks to variable-rate $\mathrm{N}$ application may be able to capture this inefficiency for the benefit of all. Of course, such an effort would require identifying stakeholder values in addition to characterizing an area's efficiency frontier. In a recent publication focusing on a type of boundary organization entitled Landlabs (Jordan et al. 2013), evidence is provided that public-private partnerships could optimize land use and meet a triple bottom line of environmental, economic, and social profit. We believe that $\mathrm{N}$ inefficiency could be successfully reduced through a similar effort to connect stakeholder preferences across the spectrum, from land managers and crop consultants to urban water users.

The analysis tells us that there are specific areas within our study region where $\mathrm{N}$ use engagement should occur first. Heterogeneous environments such as Watonwan County should be modeled at higher spatial resolutions, and local communities should be engaged to explore potential opportunities surrounding increasing agroecosystem-wide $\mathrm{N}$ use efficiency. For this to occur in a transformative way in the Mississippi River basin, this type of analysis and the subsequent engagement will need to be easily repeated by university extension agents, community organizers, and other decision support personnel with minimal resources. Implementing the SAF, although simple conceptually, requires that those implementing it have a substantial amount of technical knowledge surrounding spatial data, geographic information systems, and computer processing. Currently, there are technical barriers to accessing the data and time barriers to processing the data once they are acquired to do the analysis, even though the data are often publicly available. Additionally, selecting simple yet robust models is time consuming and is an unrealistic expectation for the average extension educator or community organizer. Although the limitations surrounding modeling are being actively addressed in settings such as the Natural Capital Project (http://www.naturalcapitalproject.org), data preprocessing still remains a limiting factor. Finally, additional work needs to be done to establish a robust process that enables multiple stakeholders' voices to be heard and enables stakeholders to interact with and test the assumptions of the baseline data and models (Jordan et al. 2013, Runck et al. 2014).

Our results must be interpreted within the context of the models' limitations. As implemented, the CERES-Maize model lacks the ability to capture the full range of response across soil types present in the study area and greatly generalizes soil textures (Table A1.1). Moreover, it relied upon one representative year of weather data, which simplifies analysis at the expense of capturing variability in the production of these ecosystem services, particularly in light of an increasingly variable climate (Motha and Baier 2005). GWAVA-S, although adequate for an initial exploration, does not fully capture the complexity of midwestern U.S. hydrology and the nature of the disservices produced through nitrate loading. For example, GWAVA-S responds to drainage, a major factor in our study region, by predicting less pollution; however, this $\mathrm{N}$ ends up in waterways and contributes to environmental degradation through other avenues (Alexander et al. 2008). Many highly important input parameters, including surface drainage, are calculated at a county scale and do not reflect this variability across space at the $1-\mathrm{km}^{2}$ resolution of the model. Finally, neither model incorporates other land management practices, including the timing of $\mathrm{N}$ application, tillage, and cover cropping, that all influence both $\mathrm{N}$ losses and yields (Dinnes et al. 2012). In spite of these caveats, both models accurately approximate biophysical dynamics and specific limitations, which are listed above, of our study area, meaning that the reported relative changes between $\mathrm{N}$ management scenarios are valid. Therefore, our results represent a first step toward specifying regions to engage stakeholders and investigate the trade-off between water quality and yield with more precision.

\section{CONCLUSION}

Given the debate over appropriate $\mathrm{N}$ management in the midwestern United States, new tools are needed that embrace biophysical reality and simultaneously acknowledge divergent stakeholder preferences. These tools need to be simple and easily fit into practitioners' toolboxes for engaging the public. We applied the SAF to readily accessible data to explore the highly controversial trade-off between yield and water quality in the Upper Midwest. Although we found that in many counties, the region is already producing the most water quality and yield possible across $\mathrm{N}$ application rates, other areas are ripe for improvement. These areas are characterized by highly heterogeneous soil environments; if improving the overall delivery of ecosystem services to society is the goal, then these areas should be targeted first for optimizing $\mathrm{N}$ application rates.

The impacts of the water quality and corn yield trade-off are far reaching and promote deep conflict among stakeholders. Future work should combine higher resolution models and ground validation with behavioral economic analysis and stakeholder engagement in these target areas. Specifically, conducting surveys that compare stakeholder attitudes and farmer practices with modeled results would be informative for minimizing the inefficiencies in ecosystem service delivery we have highlighted. Doing so would give a more realistic picture of trade-offs faced in these areas, as well as providing a stakeholder-based target for improving environmental and economic outcomes for all. There is much at stake, ranging from economic well-being to human and ecosystem health.

Responses to this article can be read online at: http://www.ecologyandsociety.org/issues/responses. $\mathrm{php} / 6767$ 


\section{Acknowledgments:}

We thank Jeannine Cavender-Bares, Stephen Polasky, and Michael Kantar for their encouragement and comments; and all other members of the National Center for Ecological Analysis and Synthesis working group for developing such a simple and useful framework. We also graciously acknowledge the two anonymous reviewers and the subject editor, whose comments greatly added to the depth and fullness of our arguments. P. M. Ewing was supported by the National Science Foundation Graduate Research Fellowship under Grant No. 00039202. B. C. Runck was supported by the HeugHarrison Fellowship.

\section{LITERATURE CITED}

Alexander, R. B., R. A. Smith, G. E. Schwarz, E. W. Boyer, J. V. Nolan, and J. W. Brakebill. 2008. Differences in phosphorus and nitrogen delivery to the Gulf of Mexico from the Mississippi River Basin. Environmental Science \& Technology 42(3):822-830. http:// dx.doi.org/10.1021/es0716103

Arrow, K., P. Dasgupta, L. Goulder, G. Daily, P. Ehrlich, G. Heal, S. Levin, K.-G. Mäler, S. Schneider, D. Starrett, and B. Walker. 2004. American economic association: Are we consuming too much? Journal of Economic Perspectives 18(3):147-172.

Baker, A., and S. Zahniser. 2006. Ethanol reshapes the corn market. Amber Waves 4(2):30-35.

Bator, F. M. 1957. The simple analytics of welfare maximization. American Economic Review 47(1):22-59.

Bender, R. R., J. W. Haegele, M. L. Ruffo, and F. E. Below. 2013. Nutrient uptake, partitioning, and remobilization in modern, transgenic insect-protected maize hybrids. Agronomy Journal 105 (1):161-170. http://dx.doi.org/10.2134/agronj2012.0352

Bierman, P., C. Rosen, R. Venterea, and J. Lamb. 2011. Survey of nitrogen fertilizer use on corn in Minnesota. Minnesota Department of Agriculture, St. Paul, Minnesota, USA. [online] URL: http://www.mda.state.mn.us/protecting/cleanwaterfund/ / media/C0D97703C7A84E74936431110A5FE897

Cavender-Bares, J., S. Polasky, E. King, and P. Balvanera. 2015. A sustainability framework for assessing trade-offs in ecosystem services. Ecology and Society 20(1): 17. http://dx.doi.org/10.5751/ ES-06917-200117

Crop Reporting Board, Statistical Reporting Service. 1975. June crop report. U.S. Department of Agriculture, Washington, D.C., USA. [online] URL: http://usda01.library.cornell.edu/usda/nass/ Acre//1970s/1975/Acre-06-30-1975.pdf

Davis, A. S., J. D. Hill, C. A. Chase, A. M. Johanns, and M. Liebman. 2012. Increasing cropping system diversity balances productivity, profitability and environmental health. PLoS One 7(10):e47149. http://dx.doi.org/10.1371/journal.pone.0047149

Diaz, R. J., and R. Rosenberg. 2008. Spreading dead zones and consequences for marine ecosystems. Science 321(5891):926-929. http://dx.doi.org/10.1126/science.1156401

Dinnes, D. L., D. L. Karlen, D. B. Jaynes, T. C. Kaspar, J. L. Hatfield, T. S. Colvin, and C. A. Cambardella. 2002. Nitrogen management strategies to reduce nitrate leaching in tile-drained midwestern soils. Agronomy Journal 94(1):153-171. http://dx.doi. org/10.2134/agronj2002.0153

Donner, S. D., and D. Scavia. 2007. How climate controls the flux of nitrogen by the Mississippi River and the development of hypoxia in the Gulf of Mexico. Limnology and Oceanography 52 (2):856-861. http://dx.doi.org/10.4319/10.2007.52.2.0856

Dowle, M., T. Short, S. Lianoglou, and S. Srinivasan. 2013. data. table: Extension of data.frame. $\mathrm{R}$ package version 1.8.8. The $\mathrm{R}$ Project for Statistical Computing, Vienna, Austria.[online] URL: http://CRAN.R-project.org/package=data.table

Duffy, M. 2013. Estimate costs of crop production in Iowa-2013. FM-1712. File A1-20. Iowa State University Extension and Outreach, Ames, Iowa, USA. [online] URL: http://www2.econ. iastate.edu/faculty/duffy/documents/EstimatedCostsofCropProduction2013.pdf

Environmental Systems Research Institute (ESRI). 2010. ArcGIS desktop: release 10. ESRI, Redlands, California, USA.

Gallandta, E. R., M. Liebmanb, and D. R. Huggins. 1999. Improving soil quality: implications for weed management. Journal of Crop Production 2(1):95-121.

Giglierano, J. D., and M. Mohan. 1990. State and county boundaries of the state of Iowa. Iowa Department of Natural Resources, Iowa Geological Survey, Iowa City, Iowa, USA. online [URL]: ftp://ftp.igsb.uiowa.edu/gis library/IA State/

Admin_Political_Boundary/county.zip

Good, A. G., and P. H. Beatty. 2011. Fertilizing nature: a tragedy of excess in the commons. PLoS Biology 9(8):e1001124. http:// dx.doi.org/10.1371/journal.pbio.1001124

Grothendieck, G. 2012. Sqldf: perform SQL selects on $R$ data frames. $\mathrm{R}$ package version 0.4-6.4. The $\mathrm{R}$ Project for Statistical Computing, Vienna, Austria. [online] URL: http://CRAN.Rproject.org $/$ package $=$ sqldf

Jagtap, S. S., and J. W. Jones. 2002. Adaptation and evaluation of the CROPGRO-soybean model to predict regional yield and production. Agriculture, Ecosystems \& Environment 93(1):73-85. http://dx.doi.org/10.1016/S0167-8809(01)00358-9

Johnson, K. A., S. Polasky, E. Nelson, and D. Pennington. 2012. Uncertainty in ecosystem services valuation and implications for assessing land use tradeoffs: an agricultural case study in the Minnesota River Basin. Ecological Economics 79:71-79. http:// dx.doi.org/10.1016/j.ecolecon.2012.04.020

Jones, J. W., G. Hoogenboom, C. H. Porter, K. J. Boote, W. D. Batchelor, L. A. Hunt, P. W. Wilkens, U. Singh, A. J. Gijsman, and J. T. Ritchie. 2003. The DSSAT cropping system model. European Journal of Agronomy 18(3):235-265. http://dx.doi. org/10.1016/S1161-0301(02)00107-7

Jordan, N., L. A. Schulte, C. Williams, D. Mulla, D. Pitt, C. S. Slotterback, R. Jackson, D. Landis, B. Dale, D. Becker, M. Rickenbach, M. Helmers, and B. Bringi. 2013. Landlabs: a new approach to creating agricultural enterprises that meet the triple bottom line. Journal of Higher Education, Outreach \& Engagement 17(4):175-200.

Keeler, B. L., S. Polasky, K. A. Brauman, K. A. Johnson, J. C. Finlay, A. O'Neill, K. Kovacs, and B. Dalzell. 2012. Linking water 
quality and well-being for improved assessment and valuation of ecosystem services. Proceedings of the National Academy of Sciences of the United States of America 109(45):18619-18624. http://dx.doi.org/10.1073/pnas.1215991109

Marcotty, J. 2012. The muddy Minnesota River comes back to life. StarTribune, 12 November.

Marsh, J. M. 2007. Cross-sector relationships between the corn feed grains and livestock and poultry economies. Journal of Agricultural and Resource Economics 32(1):93-114.

McBratney, A., B. Whelan, T. Ancev, and J. Bouma. 2005. Future directions of precision agriculture. Precision Agriculture 6 (1):7-23. http://dx.doi.org/10.1007/s11119-005-0681-8

Meersman, T. 1999. Pollution poisons a river once proud. StarTribune, 11 December.

Minnesota Department of Natural Resources. 2003. Minnesota county boundaries. DNR Data Deli. Minnesota Department of Natural Resources, St. Paul, Minnesota, USA. online [URL]: http://deli.dnr.state.mn.us/

Motha, R. P., and W. Baier. 2005. Impacts of present and future climate change and climate variability on agriculture in the temperate regions: North America. Climatic Change 70 (1-2):137-164. http://dx.doi.org/10.1007/s10584-005-5940-1

Mueller, N. D., J. S. Gerber, M. Johnston, D. K. Ray, N. Ramankutty, and J. A. Foley. 2012. Closing yield gaps through nutrient and water management. Nature 490(7419):254-257. http://dx.doi.org/10.1038/nature11420

National Agricultural Statistics Service. 2009. 2007 Census of agriculture. Volume 1. Geographic area series. Part 51. U.S. Department of Agriculture, Washington, D.C., USA. [online] URL: http://www.agcensus.usda.gov/Publications/2007/Full_Report/ usv1.pdf

National Agricultural Statistics Service. 2011. Statistics of fertilizers and pesticides. Pages XIV-1-XIV-22 in Agriculture statistics. U.S. Department of Agriculture, Washington, D.C., USA.

National Agricultural Statistics Service. 2012b. Corn for grain 2012 yield harvested per acre by county for selected states. U.S. Department of Agriculture, Washington, D.C., USA. online [URL]: http://www.nass.usda.gov/Charts_and_Maps/Crops_County/ pdf/CR-YI12-RGBChor.pdf

National Agricultural Statistics Service. 2012a. CropScapecropland data layer. U.S. Department of Agriculture, Washington, D.C., USA. [online] URL: http://nassgeodata.gmu. edu/CropScape/

National Agriculture Statistics Service. 2012c. Quick stats. National Agriculture Statistics Service, Washington, D.C., USA. [online] URL: http://quickstats.nass.usda.gov

National Atlas of the United States. 2012. The national map smallscale collection. U.S. Geological Survey, Reston, Virginia, USA. online [URL]: http://nationalatlas.gov/atlasftp-1m.html

Nolan, B. T., and K. J. Hitt. 2006. Vulnerability of shallow groundwater and drinking-water wells to nitrate in the U.S. Environmental Science \& Technology 40(24):7834-7840. http://dx. doi.org/10.1021/es060911u
Osborne, S. L., J. S. Schepers, D. D. Francis, and M. R. Schlemmer. 2002. Detection of phosphorus and nitrogen deficiencies in corn using spectral radiance measurements. Agronomy Journal 94 (6):1215-1221. http://dx.doi.org/10.2134/agronj2002.1215

Pitt, D. 2013. Iowa copes with nitrate surge in drinking water. Reading Eagle, 5 June. [online] URL: http://www2.readingeagle. com/article. aspx?id $=482877$

Polasky, S., S. R. Carpenter, C. Folke, and B. Keeler. 2011. Decision-making under great uncertainty: environmental management in an era of global change. Trends in Ecology \& Evolution 26(8):398-404. http://dx.doi.org/10.1016/j.tree.2011.04.007

Polasky, S., E. Nelson, J. Camm, B. Csuti, P. Fackler, E. Lonsdorf, C. Montgomery, D. White, J. Arthur, B. Garber-Yonts, R. Haight, J. Kagan, A. Starfield, and C. Tobalske. 2008. Where to put things? Spatial land management to sustain biodiversity and economic returns. Biological Conservation 141(6):1505-1524. http://dx.doi. org/10.1016/j.biocon.2008.03.022

Porter, P., D. Allan, K. Crookston, M. Harbur, and K. Olson. 2006. Overview of the University of Minnesota variable input crop management systems (VICMS) trials. Pages 99-116 in J. Raupp, C. Pekrun, M. Oltmanns, and U. Köpke, editors. Longterm field experiments in organic farming. Scientific Series 1. International Society of Organic Agriculture Research (ISOFAR), Berlin, Germany.

Powlson, D. S., T. M. Addiscott, N. Benjamin, K. G. Cassman, T. M. de Kok, H. van Grinsven, J.-L. L'Hirondel, A. A. Avery, and C. van Kessel. 2008. When does nitrate become a risk for humans? Journal of Environmental Quality 37(2):291-295. http:// dx.doi.org/10.2134/jeq2007.0177

R Development Core Team. 2011. R: a language and environment for statistical computing. R Project for Statistical Computing, Vienna, Austria. ISBN 3-900051-07-0. [online] URL: http://www. R-project.org/

Rajsic, P., and A. Weersink. 2008. Do farmers waste fertilizer? A comparison of ex post optimal nitrogen rates and ex ante recommendations by model, site and year. Agricultural Systems 97(1):56-67. http://dx.doi.org/10.1016/j.agsy.2007.12.001

Ribaudo, M., J. Delgado, L. Hansen, M. Livingston, R. Mosheim, and J. Williamson. 2011. Nitrogen in agricultural systems: implications for conservation policy. Economic Research Report No. (ERR-127). Economic Research Service, U.S. Department of Agriculture, Washington, D.C., USA. [online] URL: http://www. ers.usda.gov/publications/err-economic-research-report/err127.aspx

Ribaudo, M. O., R. D. Horan, and M. E. Smith.1999. Economics of water quality protection from nonpoint sources: theory and practice. Agricultural Economic Report No. 782. Economic Research Service, U.S. Department of Agriculture, Washington, D.C., USA.

Ruddy, B. C., D. L. Lorenz, and D. K. Mueller. 2006. County-level estimates of nutrient inputs to the land surface of the conterminous U.S., 1982-2001. U.S. Geological Survey Scientific Investigations Report 2006-5012. U.S. Geological Survey, Reston, Virginia, USA. [online] URL: http://pubs.usgs.gov/sir/2006/5012/

Runck, B. C., M. B. Kantar, N. R. Jordan, J. A. Anderson, D. L. Wyse, J. O. Eckberg, R. J. Barnes, C. L. Lehmand, L. R. DeHaane, 
R. M. Stupara, C. C. Sheaffer, and P. M. Porter. 2014. The reflective plant breeding paradigm: a robust system of germplasm development to support strategic diversification of agroecosystems. Crop Science 45(5):1939-1948. http://dx.doi.org/10.2135/ cropsci2014.03.0195

Sawyer, J., E. Nafziger, G. Randall, L. Bundy, G. Rehm, and B. Joern. 2006. Concepts and rationale for regional nitrogen rate guidelines for corn concepts and rationale for regional nitrogen rate guidelines for corn. Iowa State University Extension, Des Moines, Iowa, USA.

Soil Conservation Service. 1961. Agricultural handbook No. 210: land-capability classification. U.S. Department of Agriculture, Washington, D.C., USA. [online] URL: http://www.nrcs.usda. gov/internet/fse documents/nrcs142p2 052290.pdf

Soil Survey Staff. 2013. Web soil survey. Natural Resources Conservation Service, U.S. Department of Agriculture. Washington, D.C., USA. [online] URL: http://websoilsurvey. nrcs.usda.gov/

Turner, R. E., and N. N. Rabalais. 2003. Linking landscape and water quality in the Mississippi river basin for 200 years. BioScience 53(6):563-572. http://dx.doi.org/10.1641/0006-3568 (2003)053[0563:LLAWQI]2.0.CO;2

Tyrrell, T. 1999. The relative influences of nitrogen and phosphorus on oceanic primary production. Nature 400 (6744):525-531. http://dx.doi.org/10.1038/22941

Viscusi, W. K., J. Huber, and J. Bell. 2008. The economic value of water quality. Environmental and Resource Economics 41 (2):169-187.http://dx.doi.org/10.1007/s10640-007-9186-4

Wickham, H. 2009. ggplot2: Elegant graphics for data analysis. Springer, New York, New York, USA.

Wickham, H. 2011. The split-apply-combine strategy for data analysis. Journal of Statistical Software 40(1):1-29. [online] URL: http://www.jstatsoft.org/v40/i01 


\section{Supplemental Information}

\section{GWAVA-S Model Parameterization}

To focus our output to nitrogen fertilizer applied to corn only, we excluded the following layers from the original GWAVA-S calculation: Confined Manure, Population Density, Orchards and Vineyards, and Crop/Pasture/Fallow. We excluded the confined manure layer for three reasons: (1) it assumes an equal manure application rate across cropland in a county given the total application amount within the county. In our experience, this is extremely unlikely; (2) the CERES Maize model does not incorporate manure application directly; (3) it complicates comparing groundwater quality between counties with wildly disparate manure application rates. Orchards and vineyards made up less than $0.1 \%$ of cropland in our study area in 2012. The crop/pasture/fallow layer added a level of complexity in land use that detracted from our intended focus on potential yield and nitrate pollution produced per-hectare of corn planted and kilogram of $\mathrm{N}$ applied. Because GWAVA-S is a linear combination of five non-linear models, with each model corresponding to each $\mathrm{N}$ input (confined manure, population, etc.) multiplied by the transportation and attenuation subsections (Eq. 1, main paper), these manipulations are valid for capturing relative nitrate pollution dynamics due to synthetic nitrogen input.

\section{Groundwater Nitrate}

GWAVA-S input data was compiled in Arc GIS 10.0 (ESRI) and outputs calculated in $R$ (The $R$ Development Core Team). Input layers relating to "Transportation" or "Attenuation" were precompiled by Nolan \& Hitt, (2006) and downloaded from the US Geological Survey's database ('USGS GWAVA-S Data Sets - Index to all GIS Data Layers'). From these, a 'transportation-attenuation' layer was created (Fig. S2) per the equations of Nolan and Hitt (2006). We calculated a "farm fertilizer" layer assuming the entire area of each grid was fertilized and also based on the proportion of land in each grid devoted to corn (see below). GWAVA-S output representing potential yield and nitrate pollution per hectare of corn was then calculated using parameter values that Nolan \& Hitt (2006) present.

\section{CERES-Maize Model Parameterization}

The varieties chosen were the two preset variety responses with DSSAT called 2500-2600 GDD Maize and Medium Season Maize. We acknowledge that these varieties were not optimal for modeling because they represent longer developing varieties than would normally be grown in northeast Iowa, but were chosen because of data availability limitations. Our assumed planting data was May 1, 1990 with a population density of 9 plants $\mathrm{m}^{-2}$ and a row spacing of $72 \mathrm{~cm}$. It was assumed that the initial soil conditions were $100 \%$ soil moisture and $25 \mathrm{~kg} \mathrm{ha}^{-1}$ of available $\mathrm{N}$ from the previous crop, rainfall and other sources. See Table S1.

\section{Estimating Total Yield and Water Quality}

To estimate total yield and water quality at the county and study area levels, we calculated percent corn was calculated from the 2012 crop data layer (CDL) (USGS NASS). The 2012 CLD was reclassified as either corn or other and filtered with a majority (nearest 8 cells) three times to remove noise. This layer was then generalized to a $1 \mathrm{~km} * 1 \mathrm{~km}$ grid with values equating to the percentage of corn land in a particular block. Using this percent corn layer, total yield and nitrate were calculated using:

$$
0=C \cdot P
$$

Where $C$ is percent corn in a grid cell, $P$ is the potential yield or nitrate pollution a cell can produce, and $O$ is the total yield or nitrate pollution a cell can produce. 
Table S1 Yield response to nitrogen curves by soil type calculated from DSSAT CERES-Maize output. In the yield response equations, $y$ is yield and $x$ is nitrogen application rate. All equations were significant at $\mathrm{P}<0.05$ level.

\begin{tabular}{|l|c|c|c|}
\hline $\begin{array}{c}\text { Soil Surface } \\
\text { Textures in } \\
\text { STATSGO }\end{array}$ & $\begin{array}{c}\text { Associated DSSAT } \\
\text { Soil Surface } \\
\text { Texture }\end{array}$ & Yield Response Equations & $\begin{array}{c}\text { Nitrogen } \\
\text { Range } \\
\mathbf{k g ~ h a}^{-1} \mathbf{~}\end{array}$ \\
\hline $\begin{array}{l}\text { silty loam } \\
\text { clay loam } \\
\text { loam } \\
\text { silty clay loam }\end{array}$ & silty loam & $y=2086.24+47.77 x-0.082 x^{2}$ & $0-350$ \\
\hline $\begin{array}{l}\text { sandy loam } \\
\text { loamy fine } \\
\text { sand }\end{array}$ & sandy loam & $y=1203.98+38.95 x-0.048 x^{2}$ & $0-350$ \\
\hline $\begin{array}{l}\text { clay } \\
\text { silty clay }\end{array}$ & sandy clay & $y=3542.18+85.60 x-0.36 x^{2}$ & $0-125$ \\
\hline $\begin{array}{l}\text { clay } \\
\text { silty clay }\end{array}$ & sandy clay & $y=8798.82+0.31 x$ & $125-350$ \\
\hline
\end{tabular}

${ }^{\dagger}$ Soil Survey Staff, Natural Resources Conservation Service, United States Department of Agriculture. U.S. General Soil Map (STATSGO2). Available online at http://soildatamart.nrcs.usda.gov. Accessed 04/18/2013. 


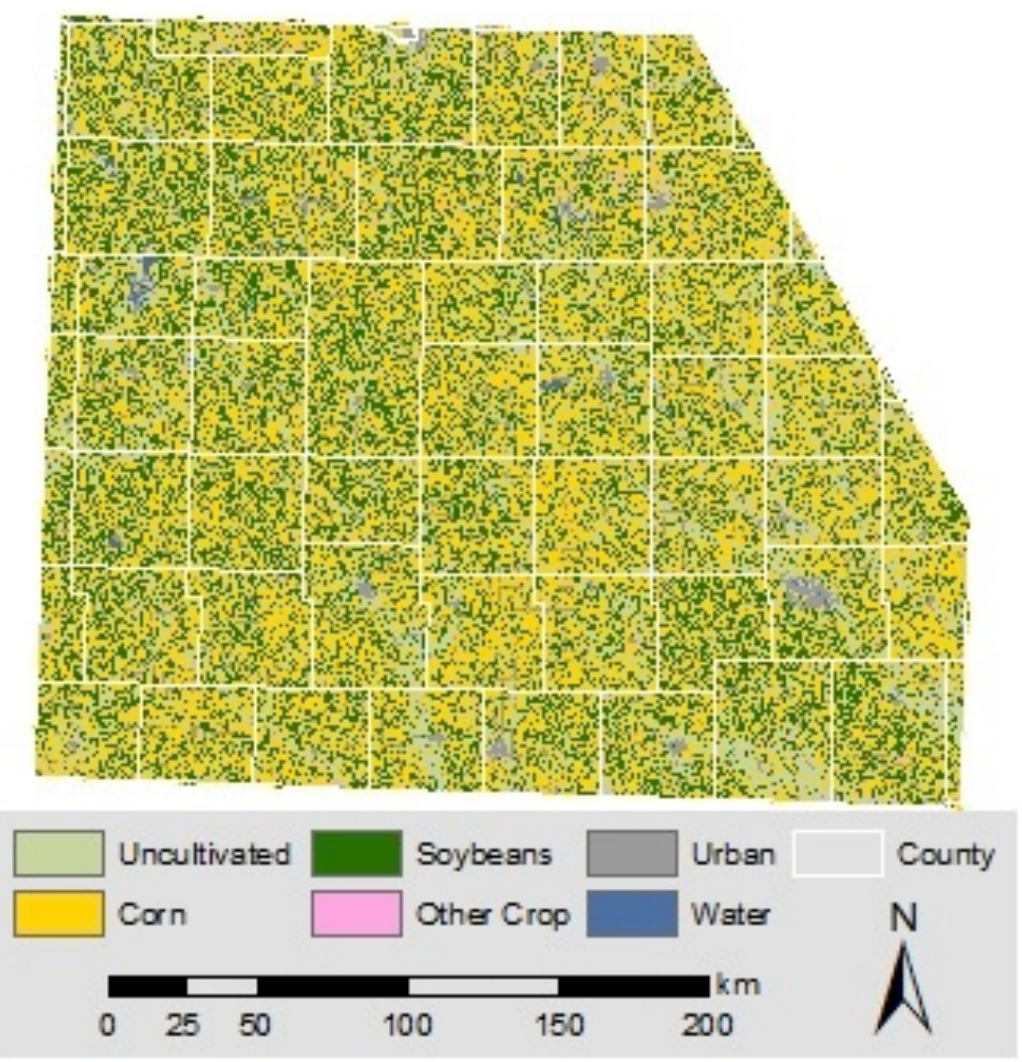

Fig. S1 Generalized Crop Data Layer from 2012 (USDA-NASS). 


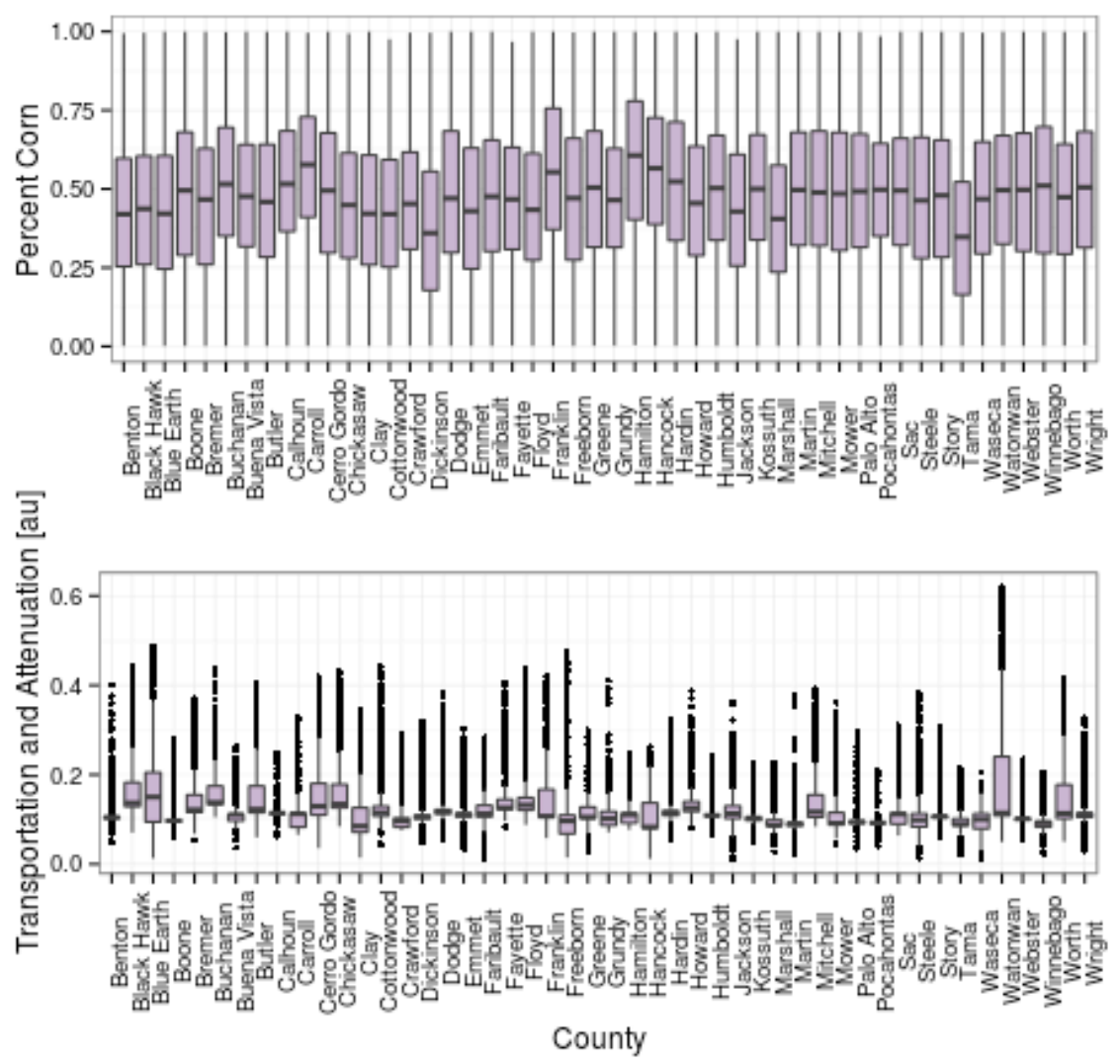

Fig. S2 Soil and management characteristics of each county. The top plot shows the dominance of corn across the study area. The data behind this plot is used to calculate total yield for each county as a function of cropped corn area. The bottom plot shows transportation and attenuation by county. All counties are greater than $10,000 \mathrm{~km}^{2}$. 